\title{
Optoelectronic Performance Analysis of Low-Energy Proton Irradiation and Post-Thermal Annealing Effects on InGaAs Solar Cell
}

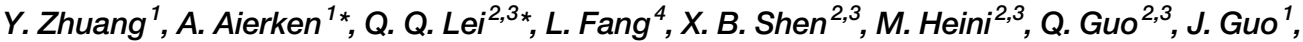
X. Yang ${ }^{1}$, J. H. Mo ${ }^{1}$, R. K. Fan ${ }^{1}$, J. $\mathrm{Li}^{1}$, Q. Y. Chen ${ }^{1}$ and S. Y. Zhang ${ }^{1}$

${ }^{1}$ School of Energy and Environment Science, Yunnan Normal University, Kunming, China, ${ }^{2}$ Xinjiang Key Laboratory of Electronic Information Materials and Devices, Xinjiang Technical Institute of Physics and Chemistry, Chinese Academy of Sciences, Urumqi, China, ${ }^{3}$ Key Laboratory of Functional Materials and Devices for Special Environments of Chinese Academy of Sciences, Xinjiang Technical Institute of Physics and Chemistry, Chinese Academy of Sciences, Urumqi, China, ${ }^{4}$ Uniwatt Technology Co. Ltd., Zhongshan, China
\end{abstract}

OPEN ACCESS

Edited by:

Zichuan Yi,

University of Electronic Science and Technology of China, China

Reviewed by:

Yang Tong,

Oak Ridge National Laboratory (DOE),

United States

Wang Xin,

South China Normal University, China

*Correspondence:

A. Aierken

erkin@ynnu.edu.cn

Q. Q. Lei

1243642152@qq.com

Specialty section: This article was submitted to

Optics and Photonics,

a section of the journal

Frontiers in Physics

Received: 21 July 2020 Accepted: 15 September 2020

Published: 12 November 2020

Citation:

Zhuang Y, Aierken A, Lei QQ, Fang L, Shen XB, Heini M, Guo Q, Guo J, Yang $X$, Mo J H, Fan RK, Li J, Chen QY and

Zhang SY (2020) Optoelectronic Performance Analysis of Low-Energy

Proton Irradiation and Post-Thermal Annealing Effects on InGaAs Solar Cell.

Front. Phys. 8:585707.

doi: 10.3389/fphy.2020.585707
The electrical and spectral properties of $150 \mathrm{KeV}$ proton-irradiated MBE-grown $\mathrm{In}_{0.53} \mathrm{Ga}_{0.47}$ As single junction solar cell and its post-thermal annealing properties were investigated. Both simulation and experimental methods were applied to analyze the irradiation-induced displacement damage and degradation mechanism of cell performance. The results show that most protons would penetrate through the $\mathrm{In}_{0.53} \mathrm{Ga}_{0.47}$ As emitter and stop in the base region, causing differing extents of electric and spectral degredation. When proton fluence were $1 \times 10^{12}$ and $5 \times 10^{12} \mathrm{p} / \mathrm{cm}^{2}$, the remaining factor of $\mathrm{I}_{\mathrm{sc}}, \mathrm{V}_{\mathrm{oc}}, \mathrm{P}_{\max }$, and $\mathrm{FF}$ were degraded to $0.790,0.767,0.558,0.921$ and $0.697,0.500,0.285,0.817$, respectively. Severer degradation was found in short wave lengths compared to long wave lengths of the solar cell spectral response. After annealing treatments, the normalized $\mathrm{I}_{\mathrm{sc}}, \mathrm{V}_{\mathrm{oc}}, \mathrm{P}_{\max }$, and $\mathrm{FF}$, significantly recovered from 0.697 , $0.500,0.285$, and 0.817 to $0.782,0.700,0.499$, and 0.912 (fluence: $5 \times 10^{12} \mathrm{p} / \mathrm{cm}^{2}$ ), and the irradiation-induced defects in the whole emission area and part of the base area were annihilated, so the observed recovery of the short wavelength of the solar cell was greater than the long wavelength. The performance analysis in this work provided valuable ways to improve the photoelectric efficiency of space solar cells.

Keywords: InGaAs solar cell, proton irradiation, displacement damage, degradation, annealing

\section{INTRODUCTION}

III-V-based multi-junction solar cells as a direct energy provider are currently used for different space applications; radiation resistance of the solar cell will directly determine the service life of spacecraft and satellites. In order to accomplish extremely tough and long-term space missions, it is important to develop space solar cells with excellent radiation resistance and high conversion efficiency and stability. Over the past ten years, lattice-matched $\mathrm{GaInP} / \mathrm{GaAs} / \mathrm{Ge}$ three-junction solar cells with relatively high efficiency ( $\eta \approx 30 \%$, in AM0, 1sun) compared to Si cells have been used as the main power source for space applications. However, the fact that sub-cells of this type of three-junction solar cells are not optimized for solar spectrum hindered the further improvement of photoelectric conversion efficiency [1-3]. So, current researchers are attempting to further improve the efficiency 
by selecting dilute nitride materials as the other sub-cell incorporated into the three-junction cell to obtain the $\mathrm{GaInP}(1.9 \mathrm{eV}) / \mathrm{GaAs}(1.4 \mathrm{eV}) / \mathrm{Ga}(\mathrm{In}) \mathrm{NAs}(\mathrm{Sb})(1.04 \mathrm{eV}) / \mathrm{Ge}(0.67 \mathrm{eV})$ four-junction solar cell $[4,5]$ in different forms, such as wafer bonding solar cells [6], upright metamorphic solar cells [7, 8], and inverted metamorphic solar cells (IMM) [9]. At present, the GaInP/GaAs//InGaAsP/InGaAs four-junction solar cell fabricated by using the wafer bonding technique not only fixed the lattice mismatch issue of multi-junction solar cells, but also obtained high photoelectric conversion efficiency compared to other new-type cells, and so is expected to become the main direction for developing the next generation of space solar cells $[10,11]$.

There are already many studies about the electrical properties of both InGaAs-based single and multi-junction solar cells. However, the radiation effects for InGaAs subcell of $\mathrm{GaInP} / \mathrm{GaAs} / / \mathrm{InGaAsP} / \mathrm{InGaAs}$ full spectra fourjunction solar cells are still limited. Dai et al. [12] studied the $1 \mathrm{MeV}$ electron irradiation effects of wafer bounded GaInP/ $\mathrm{GaAs} / / \mathrm{InGaAsP} / \mathrm{InGaAs}$ four-junction solar cells and revealed that the degradation of each InGaAs sub-cell and InGaAsP subcell are mainly responsible for the deterioration of overall performance. Walters et al. [13] studied the $1 \mathrm{MeV}$ electronirradiated $\mathrm{In}_{0.53} \mathrm{Ga}_{0.47} \mathrm{As}$ solar cell and found that electron irradiation would induce two trapping centers for the majority carrier, causing degradation of the cell performance. Karlina et al. [14] investigated the $3 / 10 \mathrm{MeV}$ proton and $1 \mathrm{MeV}$ electron radiation effects of InP/InGaAs solar cells and indicated that InGaAs is an optimum candidate for InP/InGaAs triple-junction solar cells to improve the efficiency. In our previous work, the radiation damage of $3 \mathrm{MeV}$ electron and $1 \mathrm{MeV}$ proton-irradiated $\operatorname{In}_{0.53} \mathrm{Ga}_{0.47} \mathrm{As}$ single cells was well studied and we concluded that the major degradation of spectral response (EQE) usually occurs in the long wave region [15].

Many scholars investigated the effects of proton irradiation with varying energy levels on III-V multi-junction solar cells, and concluded that the degradation caused by low-energy protons is more serious than high-energy protons [2,
16-18]. At present, there is no report about InGaAs subcells subjected to low-energy proton irradiation, especially InGaAs sub-cell designed for GaInP/GaAs//InGaAsP/InGaAs four-junction wafer bonded solar cell. So, the low-energy proton irradiated degradation mechanism of this type of solar cell is still unclear. Moreover, space solar cells work at a temperature range of $-160 \sim 200^{\circ} \mathrm{C}$ in mission $[19,20]$. When the temperature is high enough, solar cells may be annealed. Therefore, the annealing process of solar cells is an important factor that cannot be ignored. In addition, a special feature of the GaAs solar cells found in early research is their ability to recover from radiation damage by annealing at relatively low temperatures under $200^{\circ} \mathrm{C}$ [21]. So, the annealing effect on InGaAs sub-cells after low-energy proton irradiation is studied in this work, and the annealing temperature is selected as $150^{\circ} \mathrm{C}$. Research in this article is part of our ongoing project. The degradation properties of the main solar cell parameters for $150 \mathrm{KeV}$ low-energy proton-irradiated $\mathrm{In}_{0.53} \mathrm{Ga}_{0.47} \mathrm{As}$ single junction solar cells have been clearly discussed and the physical mechanism was well investigated. Moreover, the performance recovery of irradiated $\mathrm{In}_{0.53} \mathrm{Ga}_{0.47} \mathrm{As}$ under different annealing conditions is also discussed. Our experiments could provide evidence for the proper design of annealing cycles for space missions to enhance the performance of solar cells in space.

\section{EXPERIMENTAL DETAILS}

$\mathrm{In}_{0.53} \mathrm{Ga}_{0.47} \mathrm{As}$ single junction solar cell was investigated in this work and its detailed structure is shown in Figure $1 \mathbf{A}$. The cell was grown on a $350-\mu \mathrm{m}$-thick $p$-InP substrate by molecular beam epitaxy (MBE) system, and has a $3-\mu \mathrm{m}$-thick base layer with a doping concentration of $1 \times 10^{17} \mathrm{~cm}^{-3}$ and a 200-nm-thick emitter layer with a $1 \times 10^{18} \mathrm{~cm}^{-3}$ doping concentration. Si and Be were used as the n-type and p-type doping source, respectively. A detailed description for the growth and fabrication process of this solar cell has been reported in our previous work [15]. All tested samples
A

\begin{tabular}{|c|c|c|}
\hline contact & oating & \\
\hline$n^{+}-\ln P$ & window & $30 \mathrm{~nm}$ \\
\hline $\mathrm{n}^{+}-\ln 0_{53} \mathrm{Ga}_{0.47} \mathrm{As}$ & emitter & $200 \mathrm{~nm}$ \\
\hline $\mathrm{p}-\ln 0{ }_{.53} \mathrm{Ga}_{0.47} \mathrm{As}$ & base & $3000 \mathrm{~nm}$ \\
\hline$p^{+}-\ln P$ & BSF & $50 \mathrm{~nm}$ \\
\hline \multicolumn{3}{|c|}{$\mathrm{p}^{++}-\operatorname{In} \mathrm{P}$} \\
\hline \multicolumn{3}{|c|}{ back-contact } \\
\hline
\end{tabular}

B

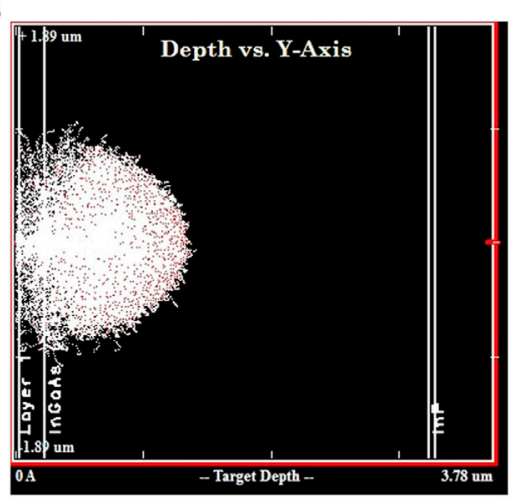

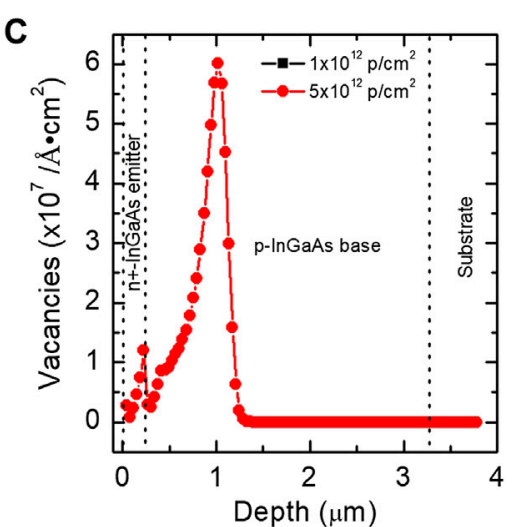

FIGURE 1 | Structure representative of (A) InGaAs sub-cells studied in this work; SRIM simulation results of (A) 150 KeV proton (number of $10^{5}$ ) trajectories and (B) calculated vacancy densities in $\ln _{0.53} \mathrm{Ga}_{0.47}$ As sub-cells. 

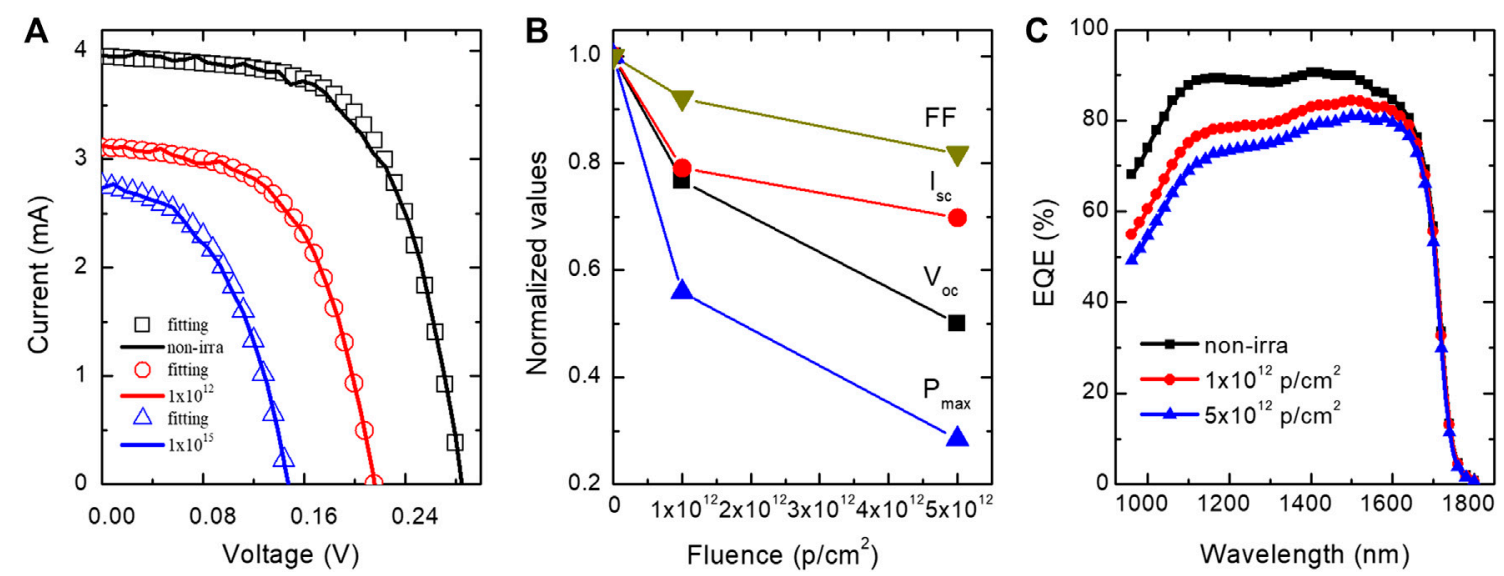

FIGURE 2 | $150 \mathrm{KeV}$ proton with different fluence-irradiated $\mathrm{In}_{0.53} \mathrm{Ga}_{0.47} A$ s solar cells' (A) I-V characteristics, solid lines are experimental curves and the theoretical values are denoted by hollow symbols, (B) the remaining factor of electrical parameters, and (C) EQE spectra.

are $2.5 \times 2.5 \mathrm{~mm}^{2}$ in size and have an initial conversion efficiency of around $11 \%$ under the standard AM0 spectra $\left(136.7 \mathrm{~mW} / \mathrm{cm}^{2}\right.$ at $\left.25^{\circ} \mathrm{C}\right)$. The $150 \mathrm{KeV}$ proton irradiation experiments were conducted at room temperature with uniform flux, and the total dose was $1.0 \times 10^{12}$ and $5.0 \times$ $10^{12} \mathrm{p} / \mathrm{cm}^{2}$ for comparison. After proton irradiation, thermal annealing treatments at $150^{\circ} \mathrm{C}$ for $20,60,120$, 180 , and $360 \mathrm{~min}$ were carried out.

\section{RESULTS AND DISCUSSION}

\section{Simulation Results}

In order to understand proton irradiation-induced displacement damage distribution in $\operatorname{In}_{0.53} \mathrm{Ga}_{0.47} \mathrm{As}$ sub-cells, the SRIM (Stopping and Range of ions in Matter) program was utilized to simulate the trajectories of $10^{5}$ incident protons. Figure $\mathbf{1 B}, \mathbf{C}$ show the trajectories of $150 \mathrm{KeV}$ protons and the corresponding irradiation-induced vacancy densities in $\mathrm{In}_{0.53} \mathrm{Ga}_{0.47} \mathrm{As}$ sub-cells. Results gathered from the simulation indicate that the maximum penetration depth would be at $1.36 \mu \mathrm{m}$ below the implantation surface, with peak damage occurring at around $1.0 \mu \mathrm{m}$, which illustrates that most protons could penetrate through InGaAs emitter region but stop in the base range. This also proves that the proton energy of $150 \mathrm{keV}$ meets the requirement for our experiments.

TABLE 1 | Extracted parameters of $\ln _{0.53} \mathrm{Ga}_{0.47}$ As solar cells from I-V curves.

\begin{tabular}{|c|c|c|c|c|c|c|c|c|c|}
\hline $\begin{array}{l}\text { Fluence } \\
\left(\mathrm{p} / \mathrm{cm}^{2}\right)\end{array}$ & $\begin{array}{c}I_{s c} \\
(m A)\end{array}$ & $\begin{array}{l}V_{\text {oc }} \\
(V)\end{array}$ & FF & $\begin{array}{l}P_{\max } \\
(\mathrm{mW})\end{array}$ & $\begin{array}{c}I_{p h} \\
(m A)\end{array}$ & $\begin{array}{l}\mathrm{I}_{0} \\
\text { (A) } \\
\text { (E) }\end{array}$ & $\begin{array}{l}R_{\text {sh }} \\
(\Omega)\end{array}$ & $\begin{array}{l}\mathbf{R}_{\mathrm{s}} \\
(\Omega)\end{array}$ & $\mathbf{n}$ \\
\hline 0 & 3.92 & 0.280 & 0.604 & 0.663 & 3.96 & $2-7$ & 1,500 & 5.5 & 1.114 \\
\hline $1 \times 10^{12}$ & 3.13 & 0.215 & 0.553 & 0.371 & 3.13 & $1.7-6$ & 1,100 & 5.6 & 1.115 \\
\hline $5 \times 10^{12}$ & 2.74 & 0.140 & 0.493 & 0.189 & 2.79 & $1.8-5$ & 900 & 5.7 & 1.114 \\
\hline
\end{tabular}

\section{Degradation of Electric and Spectral Properties}

Figure $2 \mathrm{~A}$ shows the $\mathrm{I}-\mathrm{V}$ characteristics of the $\mathrm{In}_{0.53} \mathrm{Ga}_{0.47} \mathrm{As}$ solar cell before and after proton irradiation with different proton fluence. The basic electrical parameters of solar cells, such as the short-circuit current $\left(\mathrm{I}_{\mathrm{sc}}\right)$, open-circuit voltage $\left(\mathrm{V}_{\mathrm{oc}}\right)$, fill factor $(\mathrm{FF})$, and maximum output power $\left(\mathrm{P}_{\max }\right)$, could be directly derived from the I-V curve. Other parameters, like photogenerated current $\left(\mathrm{I}_{\mathrm{ph}}\right)$, saturation current $\left(\mathrm{I}_{0}\right)$, shunt resistance $\left(R_{s h}\right)$, series resistance $\left(R_{s}\right)$, and diode ideal factor $(\mathrm{n})$, could be extracted from the I-V curves using a theoretical model [22]. The symbols shown in Figure $\mathbf{2 A}$ are fitted results and their values are listed in Table 1, which were obtained based on the equivalent circuit method described as the following expression:

$$
I=I_{\mathrm{ph}}-I_{0}\left[\exp \left(\frac{v+I R_{S}}{n V_{T}}\right)\right]-\frac{v+I R_{S}}{R_{S H}}
$$

where $V_{T}$ is the thermal voltage. It should be noticed from Figure 2A that extracted results by theoretical model are highly consistent with the experimental results. The results show that $I_{0}$ and $R_{s}$ increased with the increasing proton fluence and $\mathrm{R}_{\mathrm{sh}}$ and $\mathrm{I}_{\mathrm{ph}}$ decreased conversely.

Changes in the remaining factor of $\mathrm{I}_{\mathrm{sc}}, \mathrm{V}_{\mathrm{oc}}, \mathrm{P}_{\max }$, and $\mathrm{FF}$ of $\mathrm{In}_{0.53} \mathrm{Ga}_{0.47} \mathrm{As}$ solar cells before and after differing proton fluence irradiation levels are shown in the curves of Figure 2B. When proton fluence was $1 \times 10^{12}$ and $5 \times 10^{12} \mathrm{p} / \mathrm{cm}^{2}$, the remaining factor of $\mathrm{I}_{\mathrm{sc}}, \mathrm{V}_{\mathrm{oc}}, \mathrm{P}_{\max }$, and FF were $0.790,0.767,0.558,0.921$, and $0.697,0.500,0.285,0.817$, respectively. All of them degraded seriously when the proton fluence increased, and the $\mathrm{P}_{\max }$ was the most degraded.

The displacement damage caused by proton irradiation is mainly responsible for the degradation of $\operatorname{In}_{0.53} \mathrm{Ga}_{0.47} \mathrm{As}$ solar cells' performance and electrical parameters. When solar cells are under proton irradiation, the incident proton interacted with atoms on the pristine lattice position and transferred 
energy to the atoms by elastic or inelastic collisions, which removed atoms from their initial position, causing large amounts of defects $[23,24]$. These irradiation-induced defects introduced five types of new charge-trapping defect levels into the forbidden band, as shown in Figure 3. The first mechanism is carrier generation (labeled I), which generates electron-hole pairs assisted by thermal excitation of deep-level defects. Recombination (labeled II) occurs when it is suitable for electron-hole pairs to recombine at the defect sites, and this type of defect usually reduced the minority carrier life. Trapping (labeled III) happens when a carrier is captured by the defect level and emitted to the origin site before recombination or other processes occur. Compensation (labeled IV) occurs when the defect level obtains the free carriers from dopant atoms. The type of defect level IV could reduce the amount of the majority charge carrier. The last influence of defect level is tunneling (labeled V), where carriers can get through the depletion region through trap-assisted tunneling.

The degradation of $\mathrm{I}_{\mathrm{sc}}$ is mainly due to the displacement damage defects induced by proton irradiation in the active region of solar cells. There are two main mechanisms that cause the degradation of solar cell performance. First, the displacement damage generates non-irradiative recombination centers (defect level II in Figure 3) in the band gap to reduce the minority carrier diffusion length, and consequently decreases the collection efficiency of photo-generated carriers. The change of minority carrier diffusion length with respect to the proton irradiation flux can be expressed by the following equation [25]:

$$
\frac{1}{L_{\phi}^{2}}=\frac{1}{L_{0}^{2}}+K_{L} \phi
$$

where $\mathrm{L}_{0}$ and $\mathrm{L}_{\varphi}$ are the diffusion lengths of minority carriers before and after irradiation, and $\mathrm{K}_{\mathrm{L}}$ and $\varphi$ are the damage coefficient and the proton irradiation fluence. Equation 2 reveals that $\mathrm{L}_{\varphi}$ decreases with increasing proton irradiation fluence. Second, the carrier removal effect (defect level III and IV in Figure 3) caused by displacement damage is also an important factor resulting in the deduction of $\mathrm{I}_{\mathrm{sc}}$. The carrier removal effect would reduce the majority carrier concentration in emission and base regions and weaken the built-in electric field, so as to affect the collection of photo-generated carriers. The correlation between the built-in electric field and majority carrier concentration can been expressed as below:

$$
V_{D} \approx \frac{K_{B} T}{\mathrm{q}} \ln \left(\frac{n_{n 0} p_{p 0}}{n_{i}^{2}}\right)
$$

where $\mathrm{n}_{\mathrm{n} 0}$ and $\mathrm{p}_{\mathrm{p} 0}$ are the majority carrier concentrations of emitter and base, $\mathrm{T}$ is the temperature, $\mathrm{K}_{\mathrm{B}}$ is the Boltzmann constant, and $n_{i}$ is the intrinsic carrier concentration. It can be seen from Eq. 3 that the concentration decreased after irradiation and reduced the built-in electric field, consequently lowering the collecting efficiency of photo-generated carriers. The carrier removal effect, which reduced the majority carrier concentration, increased the series resistance $R_{s}$ of solar cells [26]. Therefore, the $R_{s}$ increased with increasing proton fluence. The fact that $V_{o c}$ decreased after proton irradiation can be explained by the following equations [27]:

$$
\begin{gathered}
V_{O C}=\frac{K_{B} T}{\mathrm{q}} \ln \left(\frac{I_{p h}}{I_{0}}+1\right) \\
I_{0} \propto J_{S}=\frac{\mathrm{q} D_{n} n_{p 0}}{L_{n}}+\frac{\mathrm{q} D_{p} p_{n 0}}{L_{p}}
\end{gathered}
$$

where $I_{0}$ is the reverse saturation current and is proportional to the reverse saturation current density $\mathrm{J}_{\mathrm{S}}, \mathrm{I}_{\mathrm{ph}}$ is the photo current, $\mathrm{L}_{\mathrm{n}}$ is the minority carrier diffusion length in p-type base region, and $L_{p}$ is the minority carrier diffusion length in the n-type emitter region. The variation of the $\mathrm{V}_{\mathrm{oc}}$ is mainly influenced by $\mathrm{I}_{0}$ and $\mathrm{I}_{\mathrm{ph}}$; both the decrease of $\mathrm{I}_{\mathrm{sc}}$ and the increase of $\mathrm{I}_{0}$ would lead to the degradation of $\mathrm{V}_{\mathrm{oc}}$. From the above analysis, it can be seen that the displacement damage defect caused by proton irradiation in the active area of $\mathrm{In}_{0.53} \mathrm{Ga}_{0.47} \mathrm{As}$ solar cells combined with the carrier removal effect in emission and base regions leads to the total degradation of $\mathrm{I}_{\mathrm{sc}}$. $\mathrm{I}_{0}$ decreases and $\mathrm{R}_{\mathrm{sh}}$ increases with the increase of proton irradiation doses. Proton irradiation produces a large number of defects in the junction region of the solar cell, which induce additional deep level defects and increase the recombination rate of electrons and holes at both sides of the junction region, and, as a result, increase the leakage current of the solar cell and decrease the $\mathrm{I}_{0}$ and $R_{s h}$ at the same time. Therefore, the change of $I_{s c}$ and $I_{0}$ is mainly responsible for the degradation of $\mathrm{V}_{\mathrm{oc}}$. In addition, Figure $\mathbf{2 A}$ and Table $\mathbf{1}$ show that the FF decreased after proton irradiation due to the decrease of $\mathrm{I}_{\mathrm{sc}}$ and $\mathrm{V}_{\mathrm{oc}}$. Finally, the degradation of $V_{o c}, I_{s c}$, and FF results in the reduction of $\mathrm{P}_{\max }$, which can be described as $\mathrm{P}_{\max }=\mathrm{FF} \times \mathrm{I}_{\mathrm{sc}} \times \mathrm{V}_{\mathrm{oc}}$.
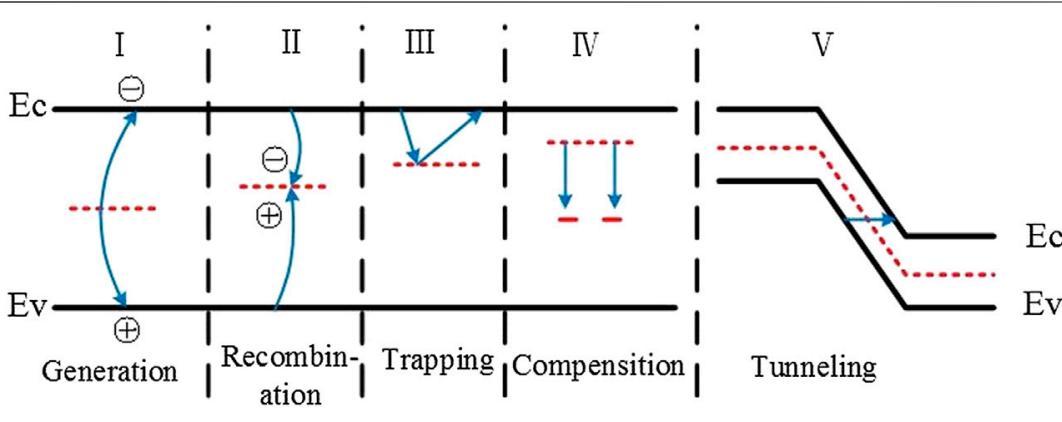

Tunneling

FIGURE 3 | Schematic diagram of irradiation-induced defect levels in band structure. 
The EQE spectra of $150 \mathrm{KeV}$ proton-irradiated $\mathrm{In}_{0.53} \mathrm{Ga}_{0.47} \mathrm{As}$ solar cells is shown Figure 2C. It can be seen that EQE degraded with the increase of proton irradiation fluence, and the degradation mainly occurred in the short-middle wavelength range. The degradation of the EQE spectral response of solar cells reveals the displacement damage located in different regions, i.e. the displacement damage of the solar cell's emission and base region will lead to the degradation of the short-wavelength and long-wavelength of the EQE spectrum, respectively [17]. According to SRIM simulation results presented in Simulation Results, protons are mainly deposited in the whole emission, junction region, and part of the base region. Therefore, $150 \mathrm{KeV}$ proton irradiation has caused displacement damage concentrated upon the whole emission region and junction region, and, consequently, more obvious degradation of EQE spectra occurs in the short-middle wavelength range.

\section{Thermal Annealing of Proton Irradiated $\ln _{0.53} \mathrm{Ga}_{0.47} \mathrm{As}$}

Thermal annealing experiments were then carried out on $\mathrm{In}_{0.53} \mathrm{Ga}_{0.47} \mathrm{As}$ single junction solar cells irradiated by $150 \mathrm{KeV}$ proton with doses of $5 \times 10^{12} \mathrm{p} / \mathrm{cm}^{2}$; the annealing temperature was set to $150^{\circ} \mathrm{C}$. For the purpose of evaluating the influence of annealing time, the duration of annealing was set to $20,60,120,180$, and $360 \mathrm{~min}$. Figure 4 shows the variation of electrical parameters for irradiated $\operatorname{In}_{0.53} \mathrm{Ga}_{0.47} \mathrm{As}$ sub-cells after different annealing times. The I- $\mathrm{V}$ characteristic curves in Figure $4 \mathrm{~A}$ reveal the significant recovery that occurred after annealing for $20 \mathrm{~min}$, but there is no substantial recovery in continuous annealing up to $360 \mathrm{~min}$. It should be noticed from Figure 4B that the electrical parameters, such as normalized $\mathrm{V}_{\mathrm{oc}}, \mathrm{I}_{\mathrm{sc}}, \mathrm{P}_{\max }$, and $\mathrm{FF}$, significantly recovered after annealing for $360 \mathrm{~min}$, changing from $0.5,0.697,0.285$, and 0.817 to 0.7 , $0.782,0.499$, and 0.912 , respectively. Figure 4C shows the degree of cell recovery as a function of annealing time in terms of the EQE. Obvious recovery occurred at $20 \mathrm{~min}$ and was maintained at around the same level during the longer annealing processing. After annealing at $150^{\circ} \mathrm{C}$ for $360 \mathrm{~min}$, the EQE of $\mathrm{In}_{0.53} \mathrm{Ga}_{0.47}$ As solar cells recovered by $7.96 \%$ and $1.15 \%$ at 1050 and $1500 \mathrm{~nm}$ wavelengths, respectively. Therefore, the recovery degree of the spectral response of $\operatorname{In}_{0.53} \mathrm{Ga}_{0.47} \mathrm{As}$ solar cells in the short wave region is greater than that in the long wave region after annealing.

After annealing at $150^{\circ} \mathrm{C}$, the performance of $\mathrm{In}_{0.53} \mathrm{Ga}_{0.47} \mathrm{As}$ solar cells irradiated by protons was obviously restored. There are two possible reasons for this phenomena. First, during the annealing process, a large number of carriers are generated inside the $\operatorname{In}_{0.53} \mathrm{Ga}_{0.47} \mathrm{As}$ solar cell, which induce a "carrier injection annealing effect", and some proton irradiationinduced defects were annihilated. This consequently increased the minority carrier life and the performance of the $\operatorname{In}_{0.53} \mathrm{Ga}_{0.47} \mathrm{As}$ solar cell could be restored [28-30]. Second, $150 \mathrm{KeV}$ proton irradiation produced a large number of displacement damage defects in the $\mathrm{In}_{0.53} \mathrm{Ga}_{0.47}$ As solar cell; some studies showed that thermal annealing can remove some of these displacement damage defects [31] and reduce the number of defects and recombination centers to improve the $\operatorname{In}_{0.53} \mathrm{Ga}_{0.47} \mathrm{As}$ solar cell's electrical and optical properties. In our work, when the $\mathrm{In}_{0.53} \mathrm{Ga}_{0.47}$ As solar cell was annealed at $150^{\circ} \mathrm{C}$, a part of the substable displacement damage caused by proton irradiation was annihilated, which resulted in a degree of recovery in cell performance. And the short wavelength recovery of EQE spectrum was more obvious than in the long wavelength. By integrating the SRIM simulation results, which showed that the damage caused by proton irradiation in the solar cell emission area was greater than in the base area, it can be seen that the degradation of the short wavelength of the solar cell spectral response was more serious. After annealing, the defects induced by proton irradiation in the whole emission area and part of the base area were annihilated, so the recovered degree of the short wavelength of the solar cell was greater than in the long wavelength.
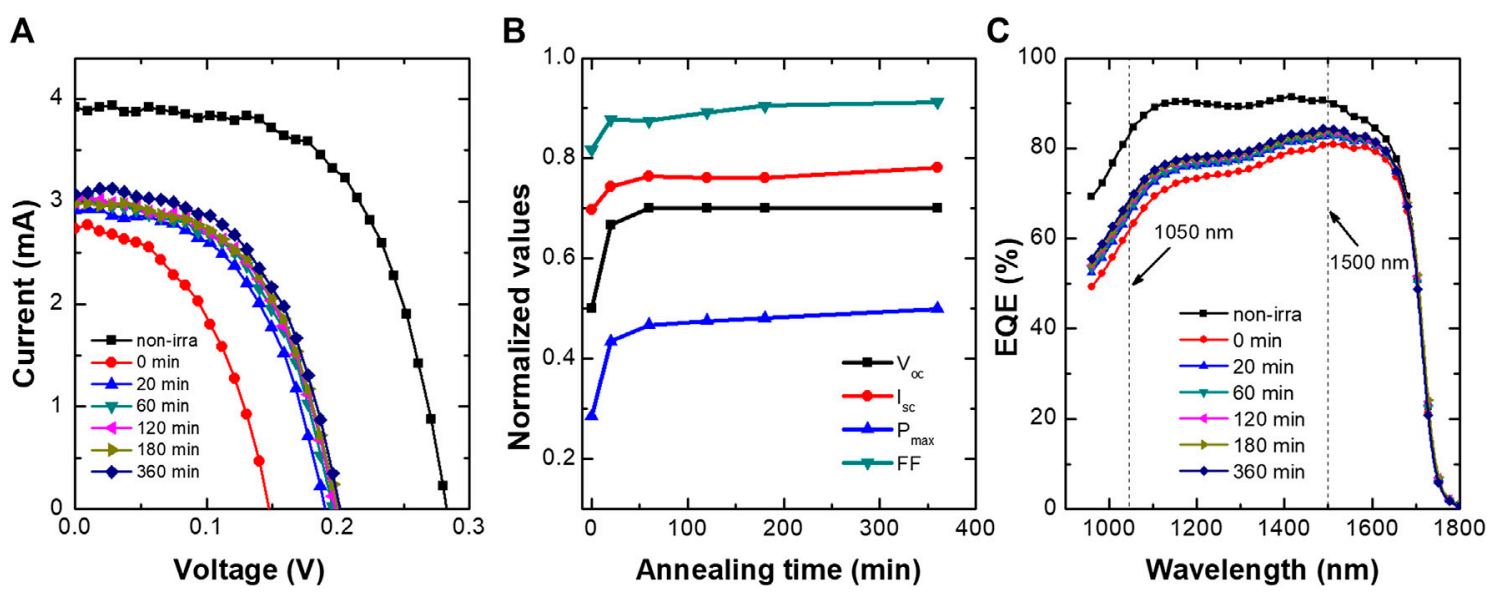

FIGURE 4 | The variation of electrical parameters (A) I-V curve and (B) normalized $V_{\mathrm{oc}}, I_{\mathrm{sc}}, \mathrm{P}_{\max }$, and FF, and the variation of (C) EQE of the solar cell of $\mathrm{In}_{0.53} \mathrm{Ga}_{0.47}$ As solar cells after annealing at $150^{\circ} \mathrm{C}$ for different times. 


\section{CONCLUSION}

In the present article, $\operatorname{In}_{0.53} \mathrm{Ga}_{0.47}$ As single junction solar cells were subjected to $150 \mathrm{KeV}$ proton radiation with different fluence. In order to understand low-energy proton irradiation-induced displacement damage distribution in $\mathrm{In}_{0.53} \mathrm{Ga}_{0.47} \mathrm{As}$ single junction solar cells, SRIM simulations were firstly carried out to simulate the trajectories of $10^{5}$ incident protons and the induced trap density. And the corresponding electrical and spectral properties after irradiation were well characterized by experimental means. The sequential annealing process from 20 to $360 \mathrm{~min}$ were then implemented to reveal the recovery of cell performance correlated with the thermal annealing treatments. The results show that most protons would penetrate through InGaAs emitter and stop in InGaAs base region, causing differing extents of electric and spectral degradation. When proton fluence was $1 \times 10^{12}$ and $5 \times 10^{12} \mathrm{p} / \mathrm{cm}^{2}$, the remaining factor of $\mathrm{I}_{\mathrm{sc}}, \mathrm{V}_{\mathrm{oc}}, \mathrm{P}_{\max }$, and $\mathrm{FF}$ were degraded to 0.790, 0.767, $0.558,0.921$ and $0.697,0.500,0.285,0.817$, respectively. Severer degradation of short wave lengths then long wave lengths of the solar cell spectral response was observed. After annealing for different time at $150^{\circ} \mathrm{C}$, it was shown that significant recovery of cell performance occurred after annealing for $20 \mathrm{~min}$, and there is no obvious substantial recovery in continuous annealing up to $360 \mathrm{~min}$. And the recovered degree of the short wavelength of the solar cell was greater than in the long wavelength, which reveals the fact that the defects induced by proton irradiation in

\section{REFERENCES}

1. King RR, Law DC, Edmondson KM, Fetzer CM, Kinsey GS, Yoon H, et al. Advances in high-efficiency III-V multijunction solar cells. Adv Optoelectron (2007) 2007:29523. doi:10.1155/2007/29523

2. Sato S-i, Miyamoto H, Imaizumi M, Shimazaki K, Morioka C, Kawano K, et al. Degradation modeling of InGaP/GaAs/Ge triple-junction solar cells irradiated with various-energy protons. Sol Energy Mater Sol Cell (2009) 93:768-73. doi:10.1016/j.solmat.2008.09.044

3. Shimazaki M. III-V compound multi-junction solar cells: present and future. Sol Energy Mater Sol Cell (2003) 75:261-9. doi:10.1016/s0927-0248(02)00168-x

4. Essig S, Stämmler E, Rönsch S, Oliva E, Schachtner M, Siefer G, et al., Dilute nitrides for 4- and 6- junction space solar cells. The 9th European space power conference; 2011 Jun 6-10; Saint Raphael, France. Noordwijk, Netherlands: European Southern Observatory Vol. 69, 978-92-9092-257-5 (2011)

5. Lei QQ, Aierken A, Sailai M, Heini M, Shen XB, Zhao XF, et al. $150 \mathrm{KeV}$ proton irradiation effects on photoluminescence of GaInAsN bulk and quantum well structures. Opt Mater (2019) 97:109375. doi:10.1016/j. optmat.2019.109375

6. Dimroth F, Grave M, Beutel P, Fiedeler U, Karcher C, Tibbits TND, et al. Wafer bonded four-junction GaInP/GaAs//GaInAsP/GaInAs concentrator solar cells with 44.7\% efficiency. Prog Photovoltaics Res Appl (2014) 22:277-82. doi:10. 1002/pip. 2475

7. Liu XQ, Fetzer CM, Rehder E, Cotal S, Mesropian S, Law D, et al. Organometallic vapor phase epitaxy growth of upright metamorphic multijunction solar cells. J Cryst Growth (2012) 352:186-9. doi:10.1016/j. jcrysgro.2011.10.024

8. Aierken A, Fang L, Heini M, Zhang Q, Li ZH, Zhao XF, et al. Effects of proton irradiation on upright metamorphic GaInP/GaInAs/Ge triple junction solar cells. Sol Energy Mater Sol Cell (2018) 185:36-44. doi:10.1016/j.solmat.2018.04.035 the whole emission area and part of the base area were annihilated. Our performance analysis could provide evidence for the proper design of annealing cycles for space missions to enhance the performance of solar cells in space.

\section{DATA AVAILABILITY STATEMENT}

The data that supports the findings of this study are available from the corresponding author upon reasonable request.

\section{AUTHOR CONTRIBUTIONS}

$\mathrm{YZ}, \mathrm{AA}$, and $\mathrm{QL}$ designed the research, conducted the experiments and wrote this manuscript. All authors contributed to the discussion of the results and edited the manuscript.

\section{ACKNOWLEDGMENTS}

This work was supported by Basic Research Foundation of Yunnan Province(Grant number: 202001AU070090), a key project of the Natural Science Foundation of China (Grant number: 61534008), and Doctoral Start-up Funding of Yunnan Normal University (Gran number: 2019XJLK05/ 01700205020503040).

9. Yoon H, Haddad M, Mesropian S, Yen J, Edmondson K, Law D, et al. Progress of inverted metamorphic III-V solar cell development at spectrolab. IEEE 33rd photovoltaic specialists conference; 2008 May 11-16; San Diego, CA. Sylmar, CA: IEEE. p. 1-6.

10. Tibbits TND, Beutel P, Grave M, Karcher C, Oliva E, Siefer G, et al. New efficiency frontiers with wafer-bonded multi-junction solar cells. In Proceedings of the 29th European photovoltaic solar energy conference and exhibition (2016) p. 1-4.

11. Yamaguchi M, Takamoto T, Araki K, Nobuaki K. Recent results for concentrator photovoltaics in Japan Jpn J Appl Phys (2016) 55:04EA05. doi:10.7567/JJAP.55.04EA05

12. Dai P, Ji L, Tan M, Uchida S, Wu Y, Abuduwayiti A, et al. Electron irradiation study of room-temperature wafer-bonded four-junction solar cell grown by MBE. Sol Energy Mater Sol Cell (2017) 171:118-22. doi:10.1016/j.solmat.2017. 06.046

13. Walters RJ, Shaw GJ, Summers GP, Burke EA, Messenger SR. Radiation effects in $\mathrm{Ga}(0.47) \mathrm{In}(0.53)$ As solar cells. 12th space photovoltaic research and technology conference; Cleveland, OH: SPRAT 12 (1993)

14. Karlina LB, Vozlovskii VV, Solov'ev VA, Shvarts MZ. The effects of irradiation on heteroepitaxial InP/InGaAs solar cells. IEEE photovoltaic specialists conference (1996) Washington, DC, p. 239-42.

15. Shen XB, Aierken A, Heini M, Mo JH, Lei QQ, Zhao XF, et al. Degradation analysis of $1 \mathrm{MeV}$ electron and $3 \mathrm{MeV}$ proton irradiated InGaAs single junction solar cell. AIP Adv (2019) 9:075205. doi:10.1063/1.5094472

16. Wang R, Guo Z, Wang G, Low-energy proton irradiation effects on GaAs/Ge solar cells. Sol Energy Mater Sol Cell (2006) 90:1052-7. doi:10.1016/j.solmat. 2005.05.018

17. Hu J-M, Wu Y-Y, Zhang Z, De-Zhuang Y, He S-Y. A study on the degradation of GaAs/Ge solar cells irradiated by $<200 \mathrm{keV}$ protons. Nucl Instrum Methods Phys Res Sect B Beam Interact Mater Atoms (2008) 266:267-70. doi:10.1016/j. nimb.2007.11.010 
18. Sumita T, Imaizumi M, Matsuda S, Ohshima T, Ohi A, Itoh H. Proton radiation analysis of multi-junction space solar cells. Nucl Instrum Methods Phys Res Sect B Beam Interact Mater Atoms (2003) 206:448-51. doi:10.1016/s0168-583x(03)00791-2

19. Barnes JA, Coswell FN. Thermoplastics for space. SAMPE Q (1989) 20(3): 22-7. doi:10.1016/S0168-583X(03)00791-2

20. Shin K-B, Kim C-G, Hong C-S, Lee H-H. Prediction of failure thermal cycles in graphite/epoxy composite materials under simulated low earth orbit environments. Compos B Eng (2000) 31(3):223-35. doi:10.1016/s1359-8368(99)00073-6

21. Loo RY, Kamath GS, Li SS. Radiation damage and annealing in GaAs solar cells. IEEE Trans Electron Dev (1990) 37(2):485-97. doi:10.1109/16.46387

22. Ciulla G, Brano VL, Dio VD, Cipriani G. A comparison of different one-diode models for the representation of I-V characteristic of a PV cell. Renew Sustain Energy Rev (2014) 32(5):684-96. doi:10.1016/j.rser.2014.01.027

23. Johnston AH. Radation damage of electronic and optoelectronic devices in space. In: 4th international workshop on radiation effects on semiconductor devices for space application; 2000 Oct 11-13; Tsukuba, Japan. Switzerland: Material Science (2000) Fourth international workshop on radiation eflects on semiconductor devices for space application (2000)

24. Luque A, Hegedus S. Handbook of photovoltaics science and engineering. 2nd ed. Chap. 8, John Wiley \& Sons, Ltd. (2011)

25. Yamaguchi M, Amano C. 60Co $\gamma$-ray and electron irradiation damage of GaAs single crystals and solar cells. J Appl Phys (1983) 54(9), 5021-9. doi:10.1063/1.332771

26. Yamaguchi M, Taylor SJ, Matsuda S, Kawasaki O. Mechanism for the anomalous degradation of Si solar cells induced by high fluence $1 \mathrm{MeV}$ electron irradiation. Appl Phys Lett (1996) 68(22):3141-3. doi:10.1063/1.115804

27. Sze SM, Ng KK. Physics of semiconductor devices. Section 1.5 and 2.3, 3rd ed., Hoboken, NJ: John Wiley \& Sons (2006)
28. Yamaguchi M, Okuda T, Taylor SJ. Minority-carrier injection-enhanced annealing of radiation damage to InGaP solar cells. Appl Phys Lett (1997) 70(16):2180-2. doi:10.1063/1.119034

29. Yamaguchi M, Okuda T, Taylor SJT, Takamoto T. Superior radiation-resistant properties of InGaP/GaAs tandem solar cells. Appl Phys Lett (1997) 70(12): 1566. doi:10.1063/1.118618

30. Ikeda M, Ando K, Yamamoto AUemura C. Injection-enhanced annealing of InP solar-cell radiation damage. J Appl Phys (1985) 58:568. doi:10.1063/1. 335664

31. Ahlgren T, Vainonen-Ahlgren E, Likonen J, Li W, Pessa M. Concentration of interstitial and substitutional nitrogen in GaNxAs1-x. Appl Phys Lett (2002) 80:2314. doi:10.1063/1.1465522

Conflict of Interest: Author LF was employed by the company Uniwatt Technology Co. Ltd.

The remaining authors declare that the research was conducted in the absence of any commercial or financial relationships that could be construed as a potential conflict of interest.

Copyright (C) 2020 Zhuang, Aierken, Lei, Fang, Shen, Heini, Guo, Guo, Yang, Mo, Fan, Li, Chen and Zhang. This is an open-access article distributed under the terms of the Creative Commons Attribution License (CC BY). The use, distribution or reproduction in other forums is permitted, provided the original author(s) and the copyright owner(s) are credited and that the original publication in this journal is cited, in accordance with accepted academic practice. No use, distribution or reproduction is permitted which does not comply with these terms. 